\title{
A CANAÃ DOS FLAGELADOS: REPRESENTAÇÃO DOS TRABALHADORES PAULISTAS NOS ROMANCES DE JOÃO DE MINAS
}

\author{
Canaan flagellated: the reception of 'paulistas' \\ working class on João de Minas' novels
}

Leandro Antônio de Almeida*

\begin{abstract}
RESUMO
João de Minas foi um escritor com uma obra literária composta de 12 livros, publicada entre 1929-1936. Uma parte de seus textos é ambientada nos grandes centros urbanos, como São Paulo e Rio de Janeiro. Nosso objetivo neste estudo é abordar como o escritor lida com a questão do trabalho e do proletariado nos seus romances sexuais e policiais. Nestes escritos, percebemos que o autor, num estilo irônico e bem-humorado peculiar, vai de encontro às narrativas paulistas hegemônicas que exaltam o progresso ao enfatizar a exploração sofrida pelos trabalhadores. Todavia, não necessariamente se engaja numa defesa destes, ao apresentá-los como portadores dos valores burgueses vigentes na época e cuja ascensão social se dava por negócios ilícitos, no caso dos homens, ou pela prostituição, no caso das mulheres.
\end{abstract}

Palavras-chave: João de Minas; proletariado; São Paulo.

\begin{abstract}
João de Minas was a writer with a literary work with twelve books published from 1929 to 1936. Some of his books are set in great towns like São Paulo and Rio de Janeiro. Our main goal in this article is to broach how the writer treats the question of work and proletarian in his detective and sexual novels. In this works we note that writer, in a proper humored ironical style, contradict the hegemonic "paulistas" fictions that exalt the progress as he stresses the exploitation suffered by workers. However, João de Minas doesn't engage himself in their
\end{abstract}

* Universidade Federal do Recôncavo da Bahia (UFRB). 
defense, but represent them having bourgeois values of that time, and whose social ascension occurred by unlawful business for men or by prostitution for women.

Key-words: João de Minas; working class; São Paulo.

\section{Introdução}

“Canaã dos Flagelados" é a metáfora utilizada pelo escritor João de Minas para se referir à metrópole paulistana ${ }^{1}$. Canaã tornou-se, na história ocidental, o símbolo da terra prometida incessantemente buscada ou da conquista e sobrevivência nessa terra. No Brasil, a apropriação literária mais famosa foi feita por Graça Aranha, num romance homônimo que tem como pano de fundo a relação de um imigrante com a paisagem brasileira. Ao contrário do sentido comum, denotando a gleba generosa, o escritor mineiro associa Canaã à cidade de São Paulo dos anos 1930, concebendo-a como espaço catalisador de esperanças. Os sujeitos da nova busca são os "flagelados", ou seja, os pobres e trabalhadores que afluíam à metrópole em busca de uma vida melhor. Como no romance de Graça Aranha, lido por João de Minas na juventude, a chegada à nova terra não implica melhoria imediata de vida, mas o defrontar-se com novos e muitas vezes ingratos desafios.

Nosso objetivo nesse artigo é estudar a representação do trabalhador paulista nos romances do escritor João de Minas $^{2}$. Analisaremos como esse

1 O termo é utilizado por João de Minas em uma crônica intitulada "Depois, miseravelmente depois", um balanço da política brasileira entre 1924 e 1934, publicada no livro Pelas terras perdidas, 1934, p. 190.

2 João de Minas era o pseudônimo utilizado pelo jornalista Ariosto Palombo para assinar artigos e livros. Nasceu em Ouro Preto por volta de 1896 e a partir de 1915 tornou-se revisor de O Minas Gerais, diário oficial da capital mineira. Em 1920, mudou-se para Uberaba, onde colaborou no Lavoura e Comércio até o final da década. A partir de julho 1927, passou a escrever dominicalmente para o carioca O Paiz, enviando seus artigos de Uberaba. Pela editora desse jornal, em 1929, lançou seu primeiro livro: Jantando um Defunto. Em setembro, foi a vez de o jornal paulista $O$ Correio Paulistano passar a receber os seus textos. João de Minas fez campanha ao lado dos paulistas para as eleições presidenciais de 1930 como membro da Concentração Conservadora, partido político mineiro que rompeu com o presidente Antonio Carlos e com o PRM quando se formou a Aliança Liberal pró-Getúlio. Talvez em função disso, ganhou uma editoria política no jornal O Paiz e mudou-se para o Rio de Janeiro em 1930, lançando mais dois outros livros intitulados Farras com o demônio e Sangue de ilusões. Com o movimento de outubro, 
tema aparece nas narrativas e como se liga a outros temas que permeiam a ficção do autor. Ao final deste artigo, por meio da questão operária, será possível compreender elementos importantes que configuram seu "mundo da obra", isto é, "proposição de mundo, de um modo tal como posso habitá-lo para nele projetar um de meus possíveis mais próprios"3, visto que

Pela ficção, pela poesia, abrem-se novas possibilidades de ser-no-mundo na realidade cotidiana. Ficção e poesia visam ao ser, mas não sob o modo do ser dado, mas sob a maneira do poder-ser. Sendo assim, a realidade quotidiana se metamorfoseia em favor daquilo que poderíamos chamar das variações imaginativas que a literatura opera sobre o real (RICOEUR, 1988, p. 54-55).

\section{Dentro dessa perspectiva teórica, é importante estudar o autor mineiro porque suas narrativas seguem a tradição de crônicas ou roman- ces de costumes urbanos das décadas de 1910 e 1920, iniciada por João}

que destituiu Washington Luís, João de Minas fugiu para Uberaba e daí para a Argentina. Retornando, estabeleceu-se em São Paulo, primeiramente nas cidades de Franca e Araraquara em 1932, e em 1933 veio para a capital trabalhar no gabinete de seu amigo Dilermando de Assis, então secretário de Viação e Obras Públicas da interventoria de Waldomiro de Lima. Colaborou por dois meses (junho e agosto) no Jornal do Estado, o diário oficial, até o fim da administração de Waldomiro, em agosto. A partir daí reorientou sua carreira, dedicando-se apenas à ficção. Recuperou seus escritos sertanistas, mixando e reeditando seus dois primeiros livros sob os títulos Mulheres e monstros (1933) e Pelas terras perdidas (1934) e lançando um novo, o Horrores e mistérios nos sertões desconhecidos (1934). Mas o forte de sua produção dessa fase foram os livros urbanos da coleção "Revolução sexual brasileira", inspirados em Benjamin Costallat, cujos títulos revelam o teor: A datilógrafa loura (1934), A mulher carioca aos 22 Anos (1934), Uma mulher... mulher! (1934), Fêmeas e santas (1935) e A prostituta do céu (1935). Em 1936, adentrou o gênero policial, publicando Nos misteriosos subterrâneos de São Paulo. Despediu-se da literatura com uma segunda edição de A mulher carioca aos 22 Anos, em 1937, pois, a partir de 1935, estabeleceu uma seita religiosa, a Igreja Brasileira Cristã Científica, com doutrina eclética de matiz nacionalista fundada no catolicismo popular, no espiritismo, na umbanda e no esoterismo. Adotando um novo pseudônimo, Mahatma Patiala, sua atividade na igreja ocupou seus esforços até pelo menos 1969 e produziu quatro edições de uma bíblia cujo primeiro volume, lançado em 1957, intitula-se $A$ vida começa na ciência divina. João de Minas morreu em Boituva em 1984.

3 Baseada no seu modelo de tríplice mimese, a noção de "variação imaginativa sobre o real" atribuída à ficção por Ricoeur nos faz ter atenção dupla: não desconsiderar numa análise os dados econômicos, sociais e culturais que serviram de "matéria-prima" ao texto, na medida em que a maior aproximação ou afastamento desses elementos tem algo a dizer sobre as intenções expressas através do próprio gênero, e não encarar um texto ficcional como cópia documental da realidade, na medida em que uma análise literária visa entender a construção de mundo habitável através da linguagem, da abordagem dos temas e de uma trama na qual se desenrolam ações das personagens. 
do Rio e desenvolvida por Benjamin Costallat, Theo Filho, Sílvio Floreal e outros. Como estes, a escrita de João de Minas é marcada pela rapidez e concisão da reportagem, com enredos folhetinescos cheios de cenas de sexo, drogas, cavação social, corrupção, incorporando a estes elementos o humor e a ironia. Todos esses escritores foram considerados "menores" sob a ótica da crítica inspirada no modernismo, mas recentemente vêm sendo recuperados por acadêmicos (SALIBA, 2002; RESENDE, 1999; COSTA, 2005; BULHÕES, 2007).

$\mathrm{Na}$ década de 30 , o tema do operário se tornava o mainstream da produção literária nacional, apesar de estar presente desde o XIX na ficção brasileira de inspiração anarquista (HARDMANN, 1983). Luís Bueno (2008), na sua história do romance de 30, aponta como momento central do romance social os anos 1933-1936, no qual a produção, a crítica e os debates intelectuais pautavam-se pela representação dos "proletários" (termo que tinha um sentido amplo, designando os trabalhadores, os pobres e desclassificados em geral). Aponta como diversos autores (intelectuais) se relacionavam com a problemática do "outro" (proletário ou a mulher), mostrando que não havia uma unidade ou consenso quanto à representação literária das personagens, do ambiente, as finalidades da literatura, da relação entre romance intimista e social. Acrescenta também a polarização intelectual entre católicos e comunistas, que enviesava a análise crítica de um romance.

Ao se dedicar a escrever romances urbanos nesses anos 30, João de Minas aproveitou-se do filão e escreveu um livro abordando diretamente o gênero: A datilógrafa loura, cujo subtítulo é "romance da mulher proletária, em S. Paulo". Não por acaso, o escritor publicou-o pela Calvino Filho, editora que contava com várias obras de orientação esquerdista no seu catálogo, como As bases sociais do marxismo e Anarquismo e socialismo, de Plekanov; Rússia, de Maurício de Medeiros; A ciência moderna na Rússia Soviética, ou obras de ficção da nova tendência literária, como A inspiradora de Luís Carlos Prestes, Menino de engenho e A bagaceira.

Inspirado nas suas matrizes estilísticas dos anos 10 e 20, a trama do romance proletário de João de Minas se desenrola em torno dos sofrimentos de Altamira, datilógrafa num escritório do arranha-céu Martinelli. Com a crise de 1929, a outrora aristocrática família do interior paulista perdeu toda riqueza baseada no plantio de café, fato que levou o chefe da família à 
morte. Junto com mãe, irmão e tia, Altamira migra para a cidade de São Paulo e, por sua beleza, é empregada pelo gordo capitalista Alfeno. Dotada de uma boa cultura adquirida quando seu pai era rico, na condição de operária Altamira enfrenta diversas situações adversas, que a levam no fim do romance a se prostituir para sobreviver. Portanto, A datilógrafa loura será o texto central para nossa análise. Todavia, também utilizaremos trechos ${ }^{4}$ de duas outras obras do autor que, ambientadas em São Paulo, citam os trabalhadores de modo fragmentado: Nos misteriosos subterrâneos de São

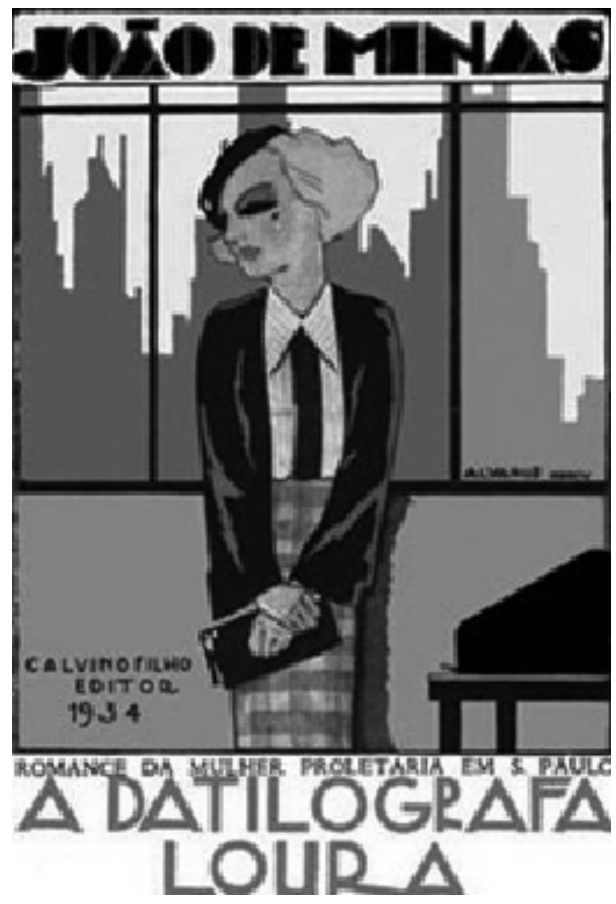

Paulo e Uma mulher... mulher $!^{5}$. Daqui por diante, serão analisados mais detidamente como os temas ligados ao operário aparecem na narrativa do escritor mineiro.

4 A utilização desses fragmentos se viabiliza porque os enredos do autor costumam ser tortuosos, contendo várias cenas ou tramas paralelas que se encerram em si, além de digressões do narrador ou das personagens. Tais procedimentos ajudam a compor o mundo do romance para o leitor ou a ressaltar aspectos do perfil das personagens principais e secundárias, permitindo que sejam tratados de maneira relativamente independente.

5 O primeiro gira em torno da investigação do investigador amador Paulo Borborema em torno dos crimes cometidos pelos gângsteres "Olhos Brancos", que aterrorizam a alta sociedade da capital paulistana. O segundo livro trata das paixões da protagonista Luciana, que vive em Araraquara. Tendo sido abandonada por Abelardo de olhos verdes quando com ele fugiu para Campinas, é secretamente protegida da maledicência da sociedade de Araraquara pelo seu apaixonado Setúbal, advogado da alta sociedade. Ao descobrir a proteção, Luciana se casa com Setúbal, mas apaixona-se pelo filho Felipe, um médico que vem da Alemanha e também possui olhos verdes. 


\section{Condições de vida nada agradáveis}

Nos romances de João de Minas, a condição de vida do trabalhador é precarizada por diversos motivos, o primeiro deles sendo o cansaço físico. O livro A datilógrafa loura inicia com Altamira sendo acordada pelo patrão no trabalho. A sonolência ocorreu porque a datilógrafa passara a noite cuidando da mãe doente. No dia seguinte, pede para sua tia Luca cuidar da enferma, visto que precisa "dormir em casa, para não dormir no trabalho, e levar pitos. Seu Alfeno pode um dia não gostar... Hoje ele me apanhou dormindo no escritório" (p. 29) Ao obter a afirmativa da tia, a datilógrafa "cansada, ela se sentou de novo. E adormeceu, triturada por todo um dia de trabalho" (p. 30).

A carestia de recursos também é uma tônica deste livro. Altamira e seu irmão Jim são apresentados o tempo todo famintos. No final do romance, procurando serviço com muita fome, a datilógrafa pede ajuda a D. Alina, que, oferecendo-lhe um prato de comida, a convence a seguir carreira no meretrício, sob seus auspícios. Outros empregados no romance são apresentados na mesma condição, como o caixeiro que a atendeu numa joalheria:

O caixeiro veio atendê-la, cansado, talvez doido de fome. Era desses caixeiros desgraçados, e que comem com o patrão, mas não dormem com ele. Mas como o patrão de manhã comeu já um boi, o patrão vai almoçar à uma hora, ou duas. E o caixeiro, que só chamou uma xícara de café matinal, aguenta calado. Senão, rua! Leis do trabalho?... Feitas para não serem cumpridas, como as dos menores... (p. 117).

Os pobres e trabalhadores também são alvo de exploração e violência que parte de outros setores sociais. Uma delas, retratada em vários romances do escritor, era a representação cínica da extorsão médica. Altamira sofre nas mãos de médicos inescrupulosos, pois, ao procurar um tratamento para o câncer de sua mãe, escuta do Dr. Juliano:

Mandei chamá-la por isto: São Paulo hospeda o dr. Strauss, operador de câncer, talvez o melhor do mundo. Chegou da Alemanha, demora-se dez dias. A senhora tem nove dias para se 
resolver a operar sua mãe. Mas ele cobra 200\$000, uma miséria, por ser a meu pedido... Pagamento, já se vê, adiantado (p. 78).

E, indagado sobre a efetiva cura da mãe da datilógrafa, responde: "Não fica. Ela tem de morrer do câncer. Mas melhora, ilude-se... [...] o cancro pode-se curar... matando-se o doente" (p. 78), completando sua impossibilidade de cura com um discurso laudatório sobre a "última palavra da ciência", a eutanásia. A exploração se torna mais gritante ao lembrarmos que a quantia exigida era maior que o ordenado mensal de Altamira, 150\$000 réis. Em Nos misteriosos subterrâneos de São Paulo, a extorsão médica também aparece: uma das vítimas da gangue dos Olhos Brancos é o médico Dr. Estader, sequestrado por possuir "mais de mil contos, arrancados aos agonizantes, negociando com a dor, cobrando juros dos túmulos" (p. 70).

No caso das mulheres, sofriam assédio constante, sempre de alguém com condição financeira superior. Em A datilógrafa loura, Altamira é assediada pelo patrão Alfeno, caricatamente apresentado com "bochechas moles, semeadas de uma barba de cinquenta anos", com uma "barriga, bem redonda, um pouco caída em cima de duas pernas finas e meio tortas, em arco" (p. 6 e 7). Com ar galanteador, que contrasta com a figura apresentada pelo narrador, tenta conquistar sua funcionária e, mal sucedido, termina por atacá-la em sua garçonière quando a datilógrafa lhe pede um adiantamento para o tratamento de sua mãe. Outra situação de assédio é mostrada no romance quando Leonardo, um comerciante italiano que assediara Altamira, é morto porque "engraçou com a mulher de um operário, queria cobrar dela uma conta de um modo que o marido não concordou..." (p. 104).

No caso dos homens, estes se veem à mercê do poder constituído, a polícia, como aconteceu com o desempregado preso por Laurentino, delegado de polícia do livro Nos misteriosos subterrâneos de São Paulo: despedido da fábrica onde trabalhava, perdeu a mulher e o filho no parto por falta de dinheiro para pagar uma parteira competente. Ao ir para um bar no Anhangabaú para esquecer os problemas e embebedar-se com os amigos, "foi então preso, como bandido do desastre do avião. Tudo isso se provou dolorosamente, depois do preso ter amargado setenta horas de geladeira, sem comer, com uma surra de borracha por cima" (p. 23-24). Esse estereótipo dos policiais acerca dos operários não era apenas de Laurentino. Seu auxiliar "Carapiá tinha a especialidade de agarrar malandros, 
e para ele todo o sujeito mal vestido e que fora despedido de um emprego era malandro". Na mesma delegacia, em outro momento, Carapiá adentrava junto com Pedrão à sala do delegado e, "aos sopapos vinham trazendo dois presos, mal vestidos e com cara de fome", dizendo: "Prendemos mais esses dois. Eles têm cara de gângster" (p. 29) ${ }^{6}$.

Assim, o escritor mineiro procura apresentar em seus livros, valendo-se da ironia, um trabalhador sempre em más condições sociais. Quando trabalham, o ordenado quase sempre é insuficiente para sua mínima sobrevivência, desproporcional ao cansaço do serviço e de outras tarefas (domésticas, que, em geral, recaem sobre as mulheres). No caso de estarem desempregados, os efeitos nocivos da penúria são maximizados, associados ao desespero e à fome. Além disso, o escritor cria uma divisão entre essa faina operária e a exploração vinda de pessoas mais endinheiradas, sejam pequenos comerciantes, profissionais liberais e empresários em geral. $\mathrm{O}$ efeito é atribuir a estes a responsabilidade pela penúria em função dos baixos salários (empresários) e altos preços dos víveres (comerciantes). Tal exploração também frequentemente é acompanhada da violência policial (homens) e sexual (mulheres). Em A datilógrafa loura, de forma mais direta, mas nos outros romances de forma esparsa, há uma divisão no mundo pautada pela posse ou ausência de dinheiro e/ou poder.

\section{Novos tempos}

Além das agruras expostas acima, no mesmo romance é mostrado como a vida das camadas trabalhadoras era precarizada devido ao modo de vida da metrópole. Reflexões esparsas, mas até que longas, permeiam a narrativa, construindo uma relação entre o ritmo acelerado e a condição do

6 Esta confusão parecia ser uma prática vigente desde o início do século. Maria Inez M. B. Pinto nos informa que os serviços temporários e mal remunerados "fazia[m] com que esta população simbolizasse a forma mais acentuada de pauperismo entre a classe trabalhadora - a fome os atormentava constantemente, suas vestimentas eram andrajosas, a morte por carência alimentar e devido às péssimas condições de moradia era normal na sua rotina diária. Alguns desses cidadãos, trabalhadores casuais da classe mais pobre, eram facilmente confundidos com indigentes que vagavam pelas ruas em busca da caridade pública para sobreviver”. PINTO, Maria Inês Machado Borges. Cotidiano e sobrevivência: a vida do trabalhador pobre na cidade de São Paulo, 1890-1914. São Paulo: EDUSP, 1994, p. 147. 
trabalho em São Paulo. O início do dia na metrópole é assim descrito em Nos misteriosos subterrâneos de São Paulo:

\begin{abstract}
A boa cidade de São Paulo amanhece correndo. Quer dizer, o seu povo noventa e nove por cento levanta mesmo da cama, mal amanhece, e sai correndo para o trabalho. Este, na cidade tentacular e sem entranhas, onde um cidadão se não abrir o olho pode morrer de fome sem a família saber, é sempre duro e puxado à sustância. Desse modo, o trabalhador é cientificamente trabalhador mesmo. É que São Paulo, sem contestação o maior parque industrial da América do Sul, trabalha produzindo construção, produzindo obras, coisas e homens muitíssimo palpáveis (p. 82-83).
\end{abstract}

E, ao final do expediente, no romance $A$ datilógrafa loura, João de Minas descreve assim o esvaziamento do Martinelli:

O formidável casarão, trinta e dois andares, único na América do Sul, todo de cimento armado em caixas frias, cômodos, salasinhas, cubículos, tudo duro e reto, fazendo um ambiente penitenciário - se esvaziava. Coisa de duas mil pessoas deixavam o arranha-céu, que marcava a vertiginosa alta falsa do café. [...] Os elevadores corriam, descendo e subindo, dando pulos entre os andares, como pavorosos gorilas negros, saltando pelos braços retorcidos de uma floresta virgem. E o ruído das ruas, lá no fundo daquilo tudo, vinha como um clamor de assalto, ou como se um choque de locomotivas subterrâneas estivesse despedaçando vidas, tábuas, ossos, ideias, prazeres, agonias, num desastre corretamente organizado, para o cinema de um pesadelo (p. 7-8).

No primeiro trecho é estabelecida a relação entre São Paulo e indústria, ambas associadas ao ritmo frenético imposto pelo tempo da máquina. O interessante é notar como o autor relaciona a produção de edifícios com a produção de pessoas, fundadas na aceleração do ritmo de vida metropolitano. As mesmas imagens aparecem no segundo trecho sintetizadas no Martinelli, à época considerada a obra-prima da construção em São Paulo, símbolo por excelência da modernidade desejada pelo discurso oficial e 
empresarial paulista. Em João de Minas, euforia é revertida ao se associar o arranha-céu a uma penitenciária e o ritmo das ruas aos ruídos insuportáveis do choque das locomotivas.

As três palavras mágicas - velocidade, trabalho, progresso - foram de tal forma positivamente associadas à identidade paulistana pelo discurso oficial na primeira metade do século XX que pareciam coladas à autopercepção da cidade e seus habitantes, como uma segunda natureza. "Trabalhar para São Paulo crescer" num ritmo frenético e alucinante parece ter-se tornado de tal forma um imperativo dos tempos modernos que apagou as identidades e memórias outras sobre a metrópole, relegando aqueles que ousassem relembrá-las ao mais completo esquecimento ${ }^{7}$.

Dessa sina também sofreu João de Minas ao captar algumas das contradições do progresso tecnológico paulistano, dentre as quais as contradições da aceleração da vida metropolitana, que estava servindo para forjar aquela imagem de uma São Paulo progressista. O autor ironicamente ressalta as implicações negativas para a vida dos trabalhadores. Em Nos misteriosos subterrâneos de São Paulo, o intenso ritmo de trabalho levava o proletário a não perceber a realidade à sua volta:

Suponhamos que o trabalhador paulista, qualquer que ele seja, encontre de manhã no seu caminho da fábrica a própria Carmen Miranda, recolhendo-se bêbada e a pé com alguns rapazes perigosos. Esse grupo conspícuo corre o risco de nem ser visto, apesar dos esbarrões que poderá levar. É que o proletariado bandeirante, estrangeiro ou não, além de andar depressa para chegar depressa, não sabe olhar, ou melhor, não sabe ver. Ele parece só olhar para o chão e apenas o bastante para não entrar debaixo de um bonde, de um automóvel, ou do carroção da limpeza pública. Cidade à parte, esta notabilíssima São Paulo! (p. 83-84).

7 Parágrafo baseado em SALIBA, Elias Thomé. História, memória, tramas e dramas da identidade Paulistana. In: PORTA, Paula. História da cidade de São Paulo. v. 3: A cidade na primeira metade do século XX. São Paulo: Paz e Terra, 2004, p. 555-587. O autor faz referência a João de Minas como um dos outros registros noturnos sobre a metrópole que foram esquecidos pela história literária ( $\mathrm{p}$. 584). Percebemos diretamente isso no romance Uma mulher.. mulher!, ao ler a notícia sobre o primeiro assassinato à metralhadora em S. Paulo, uma das personagens diz ironicamente à noiva: "Leia, e veja como São Paulo tem progredido" (p. 81). Mais adiante, uma outra personagem lamenta à colega Luciana: "São Paulo? É uma cidade de mentiras e de infâmias. Aqui tudo é falso!” (p. 85). 
Portanto, o ritmo alucinante teria o efeito de entorpecer os sentidos, impedindo uma relação descompromissada com o mundo à sua volta, a não ser a atenção mínima despendida para se orientar numa cidade onde os meios de transporte se aceleraram a ponto de colocar a vida dos pedestres em risco. A ideia é trabalhada a partir da invisibilidade nas ruas de uma famosa artista de cinema como Carmen Miranda numa situação que normalmente geraria escândalo. $\mathrm{O}$ ritmo do trabalho seria tão intenso que o povo ainda está permeado no final de semana:

O sábado na cidade dos arranha-céus é um dia que se faz um pouco mulher. [...] Esse povo em séries, o bom povo da cidade de São Paulo, está então passeando por necessidade animal, pela mesma razão por que uma criança dorme a horas certas. Esse povo trabalhou a semana toda, e destrabalha, ou ainda trabalha, isto é: trabalha na tarefa de não trabalhar... (p. 86).

O autor representa o cotidiano da capital paulista num ritmo acelerado associado à emergência da indústria e do setor de serviços - o tempo do capitalismo. O ritmo impregna-se no operário, automatizando seus modos de vida, e nem mesmo nas horas vagas consegue se libertar da temporalidade marcada pela longa jornada. Diferentemente da fome, da extorsão, do assédio e da abordagem policial, esse tipo de submissão não é sentido como tal, de tão naturalizado no modo de vida dos proletários de São Paulo.

\section{Lutas infrutiferas}

O movimento operário organizado está completamente ausente de A datilógrafa loura, seu mais direto "romance proletário". Tal ausência é um indício de que, ao contrário dos escritores vinculados ou simpáticos às correntes socialistas ou comunistas, para João de Minas a questão não passa por tais movimentos organizados. Onde aparecem tensões entre trabalhadores e patrões, na maioria das vezes ocorrem sem mediações de sindicatos ou outras instituições de classe. 
Dentre os cinco romances urbanos de João de Minas, a passagem onde aparece uma personagem envolvida no movimento operário organizado encontra-se em Uma mulher... mulher!. Setúbal, o rico marido da protagonista Luciana, tinha uma prima pobre, Ana Petrina, que ajuda os proletários rurais. Seus ideais são apresentados pelo narrador como deslocados da realidade:

Ana Petrina ia pelos quarenta anos, solteirona. Era da ilustre família Tiano, mas pobre, e arrimo da mãe. Era professora pública em Araraquara, e de noite lecionava aos meninos pobres. Fundara ultimamente uma associação cívica denominada "O Operário Agrícola Paulista está Morrendo de Fome”. Com esse gesto, afirmou definitivamente a sua reputação de maluca. Mas ganhou imenso prestígio, tornara-se uma líder feminina em todo o Oeste de S. Paulo. Aos domingos, ou sempre que fosse preciso socorrer um trabalhador agrícola faminto ou moribundo, ela percorria a cidade vestida de luto, pedindo, com um saco de boca aberta nas mãos, uma...

- esmolinha pelo amor do Brasil, para os párias das fazendas de café!... (p. 107).

Essa postura se refletia em sua aparência, pois Ana Petrina é descrita em tom caricato, num estereótipo da mulher feia e masculinizada pelo envolvimento com a luta operária:

Seca, amarelada, com pouco cabelo ruivo, óculos, voz muito doce, tinha trejeitos de palhaço. Fazia rir, usava botinas de homem, com saltos tortos. Quando se enfurecia, num discurso, na praça pública, tinha o cacoete de suspender um pouco as saias, num arranco inspirado, mostrando as canelas de cegonha (p. 107-108).

Seus esforços se mostraram válidos, congregando em torno de si alguns simpatizantes, cuja proposta é descrita de modo irônico:

Essa mulher, assim cretinizada pela mania do amparo aos míseros plantadores da riqueza do Brasil, era já um poder. Grandes homens com ela se correspondiam. E a sua instituição 
"O Operário Agrícola Paulista Está Morrendo de Fome” era já um club, com sede confortável, na Praça da Prefeitura. Aí se travavam debates eloquentes em torno à bolchevização do café, à socialização do café paulista, feita pelo governo federal com impostos medonhos (p. 108).

É importante notar como, nas obras de João de Minas, essa é a única personagem feminina envolvida diretamente com política. De forma geral, essa é uma esfera predominantemente masculina; quando muito, as mulheres ou são companheiras de políticos ou prestam-lhes serviços, como as cafetinas. João de Minas permite-lhes o acesso ao ambiente público das ruas, sendo entusiasta da liberalização dos costumes (inclusive os sexuais), mas parece negar-lhes o acesso a outra esfera pública, a da política. Tal concepção ecoa o debate, que percorreu o meio intelectual das grandes metrópoles após a Primeira Guerra Mundial, sobre a presença das mulheres (de elite) na esfera pública. A posição que restringia a mulher à esfera privada era generalizada nos meios burgueses e operários masculinos, mas contestada pelas militantes feministas mais radicais, sejam provenientes dos meios operários ou das elites ${ }^{8}$.

Ao mesmo tempo em que masculiniza a mulher envolvida na política, o escritor mineiro ataca via sátira os movimentos organizados, conferindo-lhes uma aura de fantasia desvairada ao atribuir a Ana Petrina o adjetivo de "maluca". Num ambiente intelectual brasileiro altamente polarizado entre os discursos e produções literárias filtradas pelo aspecto político, entre direita e esquerda (em geral simpática ao comunismo soviético), João de Minas adota uma postura anticomunista e pouco simpática aos movimentos organizados.

O escritor mineiro apresenta outra figura feminina das elites simpática à causa das operárias, mas representada de modo menos negativo pelo

8 "Apesar das muitas greves e mobilizações políticas que realizaram contra a exploração do trabalho nos estabelecimentos fabris entre 1890 e 1930, as operárias foram, na grande maioria das vezes, descritas como 'mocinhas infelizes e frágeis'. Apareciam desprotegidas e emocionalmente vulneráveis aos olhos da sociedade, e por isso podiam ser presas da ambição masculina. Além dos industriais intransigentes e das autoridades policiais, poucos levavam em conta figuras como as militantes operárias [...] Frágeis e infelizes para os jornalistas, perigosas e 'indesejáveis' para os patrões, passivas e inconscientes para os militantes políticos, perdidas e 'degeneradas' para os médicos e juristas, as trabalhadoras eram percebidas de vários modos”. RAGO, Margareth. Trabalho feminino e sexualidade. In: DEL PRIORE, Mary (Org.). História das mulheres no Brasil. São Paulo: Contexto, 1997, p. 578-9. 
autor: Helena Stader, do romance policial Os misteriosos subterrâneos de São Paulo. A filha do corrupto médico Stader, morto pelos gângsteres Olhos Brancos, é assim descrita: "Helena, milionária, proprietária velocíssima de um torpedo Cadillac, nascera com a alma torta. Ela tinha nervos proletários" (p. 75). Isso porque a moça

tinha inveja de todas as moças que trabalhavam para viver, ou para envelhecer, o que na mulher é uma forma de morrer duas vezes. A principesca jovem adorava a luta moderna da mulher masculina, a mulher que tem o espírito calçado de sapatões quarenta e quatro, bico largo, marchando na vida em passos de carga (p. 75-76).

Devido a essa postura, ela tinha muitas amizades,

sabendo-se fazer querida ao ponto de ser acatada como uma líder das aspirações trabalhistas das pequenas que almoçam um sanduíche nos bares automáticos, mas em compensação trabalham doze horas por dia, com as unhazinhas rebrilhando e o ruge inalterado nos lábios (p. 76).

Se Helena não se identificava com os lugares aristocráticos, como “os chás do Mappin, do Esplanada, das cavernas elegantes dos arranha-céus, onde a mulher fina e inútil mostra toilettes dengosas" (p. 76), tampouco se identificava com a militância à moda de Ana Petrina, apesar de sua formação:

Culta, normalista, lendo Bernard Shaw, Dekobra e Pirandello no original, Helena poderia perfeitamente tornar-se um espantalho literário, uma feminista ao estilo comum, querendo salvar o seu sexo com discurseiras, mau hálito e visitas às redações. Ela achava, porém, que a pior maneira da mulher emancipar-se era a intelectual, ou livresca (p. 76).

O "inferno" que seduzia Helena era trabalhar "como um burro numa casa comercial, no fundo pestilento de um escritório, diante de uma Remington, ou batendo as ruas, agarrada a uma pasta, oferecendo a venda 
de mercadorias" (p. 76-77), visto que ela preferia "o combate prático e duro, sem cabotinismo, ou a luta, o arranca-rabo profissional" (p. 76). E assim ela é apresentada na narrativa, trabalhando num café no centro de São Paulo. Isso tudo não excluía suas aspirações de mulher, isto é, arranjar um bom amante para "amar romanticamente", segundo os preceitos do "amor livre", o que acaba ocorrendo no desenrolar do romance, quando, na cafeteria, se enamora de Roberto, filho de um importante magnata de S. Paulo (um dos gângsteres dos Olhos Brancos).

O modo de vida que Altamira vivia por condição, Helena Stader vivenciava por opção, mas na perspectiva de melhorar o cotidiano de trabalho de suas companheiras operárias. É interessante notar como Helena parece encarnar a alternativa anarquista da solução da mulher e da questão proletária, pois aposta na luta cotidiana no trabalho e defende um discurso sobre o "amor livre", isto é, sem a opressão do casamento. Notamos a simpatia do narrador pela aproximação direta com a condição operária, quase tornando Helena uma líder operária eleita por suas colegas.

Se, na obra de João de Minas, as agruras do proletariado são principalmente representadas através das mulheres, são elas que encarnam alternativas possíveis de mudança do sistema. Helena Stader e Ana Petrina são mulheres cultas provenientes da elite e adotam a luta a favor do proletariado por opção, mas seus destinos tomam rumos distintos. Ao final dos romances, ambas não aparecem concretizando as aspirações em prol das camadas desfavorecidas: Helena porque se envolve com seu amante no caso policial dos assassinos de seu pai e não trata mais do projeto que movia suas aspirações; Ana Petrina porque é reprimida pelo poder constituído, pois, em função da sua militância política a favor de Getúlio, em 1932 (nota-se que a causa era partidária e não classista), "deportaram então Ana Petrina [de Araraquara] para Mato Grosso, num vagão de gado, amarrada como um porco. E até hoje não se sabe de sua sorte" (Uma mulher... mulher!, p. 189).

Nos livros do escritor mineiro, a atuação política e/ou social sincera em favor dos pobres e dos proletários tem uma eficácia efêmera e circunscrita. Apesar do potencial real de mudança social, as forças contrárias ainda são mais poderosas e numerosas. Com estas forças só se pode lidar quando se tem algo que interessa aos ricos e poderosos, seja dinheiro (Helena) ou status social elevado (Ana Petrina), através do que se estabelece um campo de forças minimamente favorável, que permanece enquanto durar 
a eficácia dos elementos acima descritos. Logo, a militância política ou social, empreendida por simpatizantes intelectuais das elites, por ocorrer por opção e não por condição, é um beco sem saída. Aos operários, em função da sua pobreza, o combate não é cogitado nos textos do autor mineiro, e a alternativa para sair da pobreza parece ser outra.

\section{Formas de ascensão}

Nas obras de João de Minas, os ideais de riqueza e luxo próprios das elites parecem incorporados à consciência dos proletários. Arlindo, personagem de A datilógrafa loura, utiliza-se desses ideais da arte e do cinema para atrair moças para sua garçonière:

Nós lhe enfiamos nas cabeças sonetos, ideias de arte, cançonetas, tangos argentinos, gemido de violino, e... bebidas, em lindos cálices. [...] Damos às pequenas retratos de artistas de Hollywood, com autógrafos falsificados. Fazemos-lhes preleções sobre a vida sublime das atrizes, as maravilhas do cinema... (p. 36-37).

E, quando a operária torna-se prostituta internacional de luxo, segundo a fala cínica do "poeta" Arlindo, poderia satisfazer todos os seus sonhos:

Quando chega a esse ponto supremo da sabedoria, pode ser tudo, até rainha... Começa, por exemplo, sendo deusa. Logo se enche de joias, cava palacetes, vai à Europa, aprende a estourar champanhe... entra para o teatro, para o cinema, ou mesmo se casa na alta sociedade apatacada, no mundo dos coronéis, dos marchantes. Como você vê, no fundo, a finalidade dos 13 Vampiros é fazer a felicidade real, efetiva, das pálidas datilógrafas, das tristes empregadinhas de escritório. Não somos uns beneméritos? (p. 38-39).

Altamira não está imune a esses ideais. A datilógrafa loura também tinha seus delírios de riqueza ao passar em frente às vitrines e ficava 
embasbacada admirando joias caras, para esquecer da fome. É quando a recebe o faminto caixeiro acima citado:

- Então a senhora quer ver um diamante azulado?

- Azulado. Róseo, já tenho. Quero agora comprar um diamante azulado. Me veja uma pedra da pontinha.

E como uma milionária pouco exigente, sorriu para o caixeiro. [...] Altamira escolheu um solitário magnífico. 4 contos. Não, não era caro... (p. 168).

Esse livro é organizado de forma cíclica. No início do livro, quando Altamira deixa seu trabalho, um carro de luxo quase a atropela. E reflete: "E quem será essa mulher, tão cheia de joias?... Por certo não é uma pobre, uma mísera empregada de escritório, como eu...” (p. 9). E o romance termina com um automóvel no qual ia uma moça loira cheia de joias e diamantes:

Uma das escravas brancas do conde Matarazzo disse para a outra:

-- Ucê viu, Giuseppina? Qui mulher bonita, Giuseppina! É a Dina Thereza, no meno.

- Boba! Ucê num sabe qui a Dina é morena?... Essa é a filhia do presidente da Argentina. Ucê num viu o bruto otomovel?

- Num ha como nascer rica! Me da uma tristeza... - filosofou a Berterella, amiga de Giuseppina.

Era Altamira, que ia no Renault (p. 168)9.

A consciência guardiã dos ideais de moral e virtude é o elo mais fraco que se rompe quando há uma tensão extrema contra a realidade social, no caso de Altamira a sucessão de desgraças que lhe ocorrem (desemprego, fome, prisão do irmão, doença da mãe, abandono amoroso), intensificada pelos seus ideais de riqueza. Altamira, após recusar o diamante acima citado, oferecido por um velho rico em troca de sexo, novamente reflete consigo:

9 Margareth Rago nota como essa era uma das formas das prostitutas aparecerem em público: "Invadindo o centro, as prostitutas procuravam exibir-se ostensivamente, como Marcelle d'Avreux, desfilar em carros abertos, expor o corpo ornamentado aos olhares curiosos nos espaços elegantes da vida boêmia, ou nas ruas ocupadas pelo baixo meretrício. Exibir-se como mercadoria significava revelar o status social da meretriz, propagandeando-se." RAGO, Margareth. Os prazeres da noite: prostituição e códigos da sexualidade feminina em São Paulo, 1890-1930. Rio de Janeiro: Paz e Terra, 1991, p. 81-82, 
E dizer que ela, minutos antes, "morta de fome", "jogara fora" um brilhante azulado!... Mas, se ela o aceitasse, e as consequências, e os beijos e lambeções do velho da bigodeira?... Veio-lhe uma ideia, que entrou no seu espírito como um ratinho ágil, que sai de um buraco invisível: ninguém saberia, tudo seria em segredo... assim um mistério... uma aventura... Mas... e a sua consciência, o seu caráter? Ela ficou pasmada, olhando vago. Descobria que, na "realidade", essas coisas não existem. Mas por que foram inventadas? "Deviam ter sido inventadas pelos industriais, pelos agiotas, pelos açambarcadores... pelos alfenos... para terem nas suas garras, trabalhando para eles e morrendo de fome, inúmeras mulheres, homens e crianças..." Este pensamento assaltou-a, sem ela esperar. Ela repeliu-o. E começou a mexer na máquina (DL, p. 124).

Esse raciocínio retornará, no romance, na boca de Alina, que convencerá Altamira a se prostituir. Vemos então que, nos romances de João de Minas, a principal via feminina para a riqueza e fuga da opressão social é a prostituição. Altamira não aguenta sua condição proletária e se prostitui, abandonando ideais de virgindade, casamento, tornando-se inspiração de riqueza para outras operárias.

Ao lado de argumentos cientificistas de matriz biologizante, que colocavam a prostituição como uma degeneração ou uma doença ${ }^{10}$, as razões econômicas da prostituição eram apontadas desde finais do século XIX pelas autoridades oficiais, grande imprensa e pela imprensa proletária em S. Paulo. Se para o Estado e a grande imprensa, nas expressões dos médicos abolicionistas, a questão era descriminalizar a prostituta, mas ainda controlar uma prática considerada marginal porém socialmente necessária por liberar as energias sexuais masculinas, para a imprensa operária a questão estava relacionada à própria exploração do sistema capitalista, que transformava o corpo da mulher operária em mercadoria de consumo para as classes abastadas da sociedade ${ }^{11}$. Em ambos os argumentos, era grande o peso das

10 RAGO, Margareth. Os prazeres da noite: prostituição e códigos da sexualidade feminina em São Paulo, 1890-1930. Rio de Janeiro: Paz e Terra, 1991, p. 141-164; RAGO, Margareth. Do cabaré ao lar: a utopia da cidade disciplinar. Brasil: 1890-1930. 2. ed. São Paulo: Paz e Terra, 1987, p. 85-95.

11 RAGO, Margareth. Os prazeres da noite: prostituição e códigos da sexualidade feminina em São Paulo, 1890-1930. Rio de Janeiro: Paz e Terra, 1991, p. 130, 212, 219. RAGO, Margareth. Do cabaré ao lar: a utopia da cidade disciplinar. Brasil: 1890-1930. 2. ed. São Paulo: Paz e Terra, 1987, p. 108-110; PINTO, Maria Inês Machado Borges. Cotidiano e sobrevivência: a vida do trabalhador pobre na cidade de São Paulo, 1890-1914. São Paulo: EDUSP, 1994, p. 205-217. 
precárias condições das mulheres das classes desfavorecidas como causas do meretrício. Esse elemento social será um dos componentes importantes da imagem da prostituta-vítima, aquela que, pelas fatalidades do destino e como resposta a ele, é levada ao meretrício por razões alheias à sua vontade. Esta expressão foi utilizada por Margareth Rago no estudo da economia da imagem da prostituta nos romances paulistas da década de 20 , cujas causas seriam as seguintes: necessidades financeiras, opressão familiar, adversidades enfrentadas na cidade grande ou manipulação machista ${ }^{12}$.

O romance $A$ datilógrafa loura estrutura-se segundo esse princípio, se bem que a prostituição é muito mais o desfecho que norteador da narrativa. Altamira, no final do romance, foi arrastada para o meretrício por razões alheias à sua vontade, em função de dificuldades econômicas fruto de um mundo corrompido, como último recurso de sobrevivência. A resolução é tomada no clímax, após Dona Alina, cafetina "filósofa, da legítima", contar sua trajetória de sonhos e desilusões a Altamira:

Eu já fui como você, já tive vinte anos. Eu era toda uma ilusão, um sonho, um dia sem noite... Um bacharel escreveu inúmeros versos para mim. E casou-se... com o meu dote, umas boas casas. Aos trinta anos eu estava na miséria, e viúva, com duas meninas... Fomos procurar trabalho na indústria, no comércio, no progresso de S. Paulo. Sofremos as mais horrorosas humilhações, trabalhando como animais, como escravas, para ganhar o necessário... para morrer de fome (p. 156).

Essa vivência sofrida propiciou-lhe uma percepção aguda da realidade em que vive, o que a cafetina ensina às suas filhas, dando-lhes "uma educação moderna, no sentido econômico e sociológico", isto é, tornando-as prostitutas, pois

verifiquei o seguinte: a pessoa, trabalhando, desprestigia-se horrivelmente, passa a figurar na ralé social. Mas eu fui compreendendo o segredo do luxo e do prazer de muito figurão. Comecei a ver que tudo é negócio, cavação, egoísmo... Não

12 RAGO, Margareth. Os prazeres da noite: prostituição e códigos da sexualidade feminina em São Paulo, 1890-1930. Rio de Janeiro: Paz e Terra, 1991, p. 212-219. 
há nada neste mundo que não vise [a]o dinheiro, [a]o burro do dinheiro. E este tudo compra, absolve, embeleza. [...] Afinal, verifiquei que uma das mercadorias mais vendáveis é a mercadoria invisível, inexistente, irreal. Tudo o que é pura fantasia, mentira absoluta, vende-se formidavelmente. A virtude, a caridade, a salvação do Estado, o bem público, a paz, a ordem, o céu, o inferno etc., fantasias estúpidas, vendem-se a preços fabulosos (p. 156-157).

E quando Altamira lhe inquire sobre um possível emprego, Alina lhe propõe o meretrício, que propiciaria muitas vantagens à jovem datilógrafa:

Seu emprego?... Vou the ser franca... Eu não lhe mando para uma fábrica, um escritório, enfim um desses matadouros dos pobres honestos. Isso eu não faço. Tenho consciência. [...] Prefiro que você descanse, engorde, poupe os nervos, coma e beba como uma rainha, ponha dinheiro no banco, compre bangalôs, cure a sua mãe, ponha o seu irmão num colégio, tirando-o da rua... [...] Muito simples, minha filha. Eu tenho uma coleção de velhos milionários, meus amigos, que dão dez contos por cada menina perfeita que eu lhes arranje... por uma, duas, três noites. Eu fico com vinte por cento, o resto é da futura capitalista (p. 159-160).

A associação entre a exploração do proletariado e do corpo da prostituta não é nova, pois já de longa data fazia parte do discurso proletário, configurando o tradicional topos da prostituta vítima ${ }^{13}$. Mas, em João de Minas ela toma o sentido contrário: não há uma perspectiva do fim da condição de prostituta pela alteração das estruturas sociais ${ }^{14}$. Se não há perspectiva de mudança da sociedade, o que pode ser feito é uma utilização da prostituição como forma de ascensão social no novo mundo

13 "A prostituta trabalha, se cansa, é usada e explorada tanto quanto a operária. Por isso ela não deve ser desprezada nem marginalizada, dizem os libertários, já que é mais uma vítima da exploração do capital. Basta observar a origem social de grande parte das mulheres públicas para se dar conta de que o proletariado fornece o contingente principal". RAGO, Margareth. Do cabaré ao lar: a utopia da cidade disciplinar. Brasil: 1890-1930. 2. ed. São Paulo: Paz e Terra, 1987, p. 109.

14 "A eliminação da prostituição, portanto, só poderá ocorrer com a revolução social e a mudança radical das estruturas econômicas, com o fim do Estado e, sobretudo, com a reversão da moral burguesa." RAGO, Margareth. Do cabaré ao lar: a utopia da cidade disciplinar. Brasil: 1890-1930. 2. ed. São Paulo: Paz e Terra, 1987, p. 110. 
regido pelas mercadorias. Alina disse "tenho consciência" porque percebe que tudo é negócio, fonte de lucro, tanto é que se refere às suas meretrizes como "capitalistas", alguém que possui um bem que, colocado no mercado do poder, pode auferir lucros exorbitantes, os 8 contos de réis. No mundo dos romances de João de Minas, as cafetinas, prostitutas e alcoviteiras são as pessoas que se revelam portadoras de maior inteligência prática, uma compreensão de como funcionam as regras do sistema e como se deve fazer para sobreviver nele: renegando ou utilizando todos os valores, ideais e aparências sociais em prol do sucesso financeiro e mesmo da sobrevivência. Transformar o corpo em mercadoria, explorando o desejo alheio, é uma forma de obter poder e dinheiro.

Assim, para as operárias dotadas de muita beleza, coloca-se a alternativa: renegar seus valores e sobreviver de forma confortável ou sucumbir à exploração aferrando-se a valores que já não orientam as relações sociais, mas servem de instrumentos de dominação. Tal alternativa está aberta apenas às mulheres jovens e bonitas, capazes de seguir o alto meretrício. Já o destino das mulheres velhas que não podem usufruir do corpo é outro: ou seguem no ramo de cafetina, como Alina, ou guardam economias advindas dos tempos do meretrício, como a mãe de Luciana de Uma mulher... mulher!. Para o resto das mulheres pobres e proletárias não há alternativa senão a miséria, a exploração, a humilhação. Seria o destino de Altamira se não escolhesse sair de sua condição de proletária por meio da prostituição.

Já os homens conseguem ascender de outra forma, através de seus contatos e negócios ilícitos. Alfeno, patrão de Altamira de $A$ datilógrafa loura, fora largado pela mulher na noite de núpcias, e "até ali, aos vinte e quatro anos, só tivera pontapés do destino, no seu pobre traseiro. Empregado no comércio, nunca passara da vassoura" (p. 129-130). Tinha pretensões de entrar para o circo como palhaço, quando conheceu uma baiana quitandeira que mudou seu destino: arranjaram uma pensão no Largo da Memória que recebia os chefes políticos do interior que iam à capital. Então,

Passando a conviver com chefetes do interior, com deputados boçais, ele foi tomando pé num mundo de cavações especiais. Fez-se aos poucos intermediário de negócios (de prostitutas, de "francesas", com os seus hóspedes), agente, procurador, servidor, servidor, testa de ferro nos A pedidos da imprensa. Quando deu fé, tinha encaminhado um empréstimo para uma câmara 
municipal, Araraquara, chefiada pelo herói de um linchamento, um tal Plínio de Carvalho. Um dia, comprou por uma miséria o subsídio de três meses de um senador cocainômano. E... Estava banqueiro! (p. 131).

Daí por diante foi uma sucessão de grilagens, agenciamento de operárias para os poderosos do $\mathrm{PRP}$, fornecimentos para os batalhões de $1930 \mathrm{e}$ 1932 etc. E, aos cinquenta anos, tinha feito fortuna através desses negócios e contatos na política nacional, possuindo um "escritório de complicações comerciais e bancárias, corretagens sujas etc., no prédio Martinelli, $17^{\circ}$ andar, sala 408" (p. 6) ${ }^{15}$.

Na obra de João de Minas, a partir da própria vivência como pobres e/ou operários, personagens como Alina e Alfeno - e não são poucos compreenderam que, sem lançar mão de práticas comumente consideradas ilícitas e imorais, não podem sobreviver num mundo onde tudo é mercadoria, inclusive os valores e o próprio corpo; no qual os ideais são meios de ascensão social ou mercadorias fantasiosas a serem vendidas; num mundo onde os desejos sexuais e materiais se sobrepõem a qualquer tipo de valores morais; onde qualquer solidariedade é interessada, cabendo ou não ao jogo de forças se isso descambará para a exploração ou não; num mundo onde o egoísmo que move as pessoas se vale de mentiras e traições para atingir os seus fins; e onde alguém que não tenha nada a oferecer - seja dinheiro, poder ou beleza - está condenado à morte, à miséria e ao trabalho mal pago.

Existe nos romances de João de Minas apenas um casal que foi bem-sucedido financeiramente, tornando-se milionário somente com o esforço do trabalho: D. Joaquina e seu marido, em Nos misteriosos subterrâneos de São Paulo:

D. Joaquina era uma mulher modesta, mas de valor real. Casara-se, paulista e operária, com um napolitano forçudo e honesto, operário como ela. Os dois, trabalhando juntos, se esqueceram de que a lua de mel atrapalha o serviço e escandaliza. Um contramestre os encontrou beijando-se diante de uma máquina de

15 No livro do autor $A$ mulher carioca aos 22 anos há outra personagem construída sobre os mesmos moldes. Anfrísio, pai da protagonista Angélica, enriquecera e ascendera socialmente a partir das mesmas negociatas, ganhando o título de Comendador e comprando o título de Conde. 
pespontar calçado, funcionando vazia. Despediu-os, e eles foram para uma portinha do Brás botar remendos em calçado de carregadores nas estações. Ali mesmo começou a nascer a estupenda marca do Calçado Ronelli. Assim se fundou mais uma grande indústria em São Paulo, em cima de um beijo bravio (p. 25).

No desenrolar da história, a honestidade do trabalho do casal e a simplicidade de D. Joaquina, já viúva, são contrapostas à futilidade de sua filha Clotilde Ronelli, a qual, segundo o comentário do delegado Laurentino sobre seu assassinato, "vivia pelas garçonières chics bebendo champagne, e dizem que entregue a amores invertidos, cheia de dinheiro... quando dezenas de milhares de mocinhas morrem de fome, trabalhando nos escritórios" (p. 134). Joaquina, tendo que pagar uma fortuna pela cabeça da filha amada, mas cujos costumes modernos apenas tolerava, termina enlouquecida assistindo a um filme de terror, bradando: "Corta a cabeça delas! Corta a cabeça dessas infames... que não quiseram ser como eu, mulher ao sistema antigo... E por isso estou aqui, bem viva!"' (p. 40).

Nem neste único exemplo de riqueza honesta os operários escapam às forças corruptas do mundo. Na composição do romance, elas atingem a idosa senhora Ronelli através da filha do casal, seduzida pelo canto de sereia dos prazeres mundanos que o dinheiro dos pais possibilitava, transformando-se por opção numa arrivista chic. Como ressaltou o delegado, sua imoralidade não estava só nos seus atos, mas também no fato de não ser obrigada a trabalhar como seus pais ou suas contemporâneas e ainda assim aderir aos valores e maneiras da classe dominante. Por isso, a jovem pagou com a vida e a mãe, com a própria sanidade.

\section{Um mundo de agruras e desilusões}

Vimos que nos romances do escritor mineiro os operários sempre levam o pior na luta que se efetua no cotidiano paulista. Sofrem agruras como cansaço, fome, extorsão, assédio e violência, sem falar numa aceleração do tempo social que entorpece seus sentidos. Têm contra si o Estado (políticos e polícia), os capitalistas, os profissionais autônomos das camadas 
médias, que conseguem explorá-los utilizando-se do aparato ideológico, ou reprimi-los utilizando os mecanismos estatais de repressão. Incorporar esses temas acena para um aspecto crítico da obra do escritor, contraposto aos discursos oficiais dos anos 20 e 30 que valorizavam a nova dinâmica do trabalho e ritmo de vida, atrelando-os ao desenvolvimento da metrópole e da nação brasileira. Apesar de se valer de temas e da crítica social utilizados por autores da ficção operária do século XIX e do romance social da década de 1930, na obra João de Minas não encontramos um horizonte de libertação ou um projeto de sociedade a ser realizado. Percebemos também certo moralismo na denúncia do comportamento sórdido dos exploradores, que fazia parte dos temas dos escritores católicos dessa década. Mas nos romances de João de Minas uma vida moralmente reta não leva à redenção, mas à perdição em um mundo regido pela lógica da mercadoria. Se diferentes valores são confrontados nas falas das mais diversas personagens, a posição do narrador é sempre irônica, criando efeitos humorísticos a partir das situações narradas.

Nesse mundo construído pelo autor, o movimento social organizado ou é apanágio da boa vontade de indivíduos das elites, incapaz de mudanças significativas, ou não existe. Então, as alternativas que se apresenta, aos operários são: aderir ao sistema vigente, seja como capitalista que explora outros indivíduos e se insere em negociatas ilícitas, seja como mercadoria de luxo que obtém regalias dos clientes poderosos, ou sucumbir mantendo os próprios valores. Tais alternativas criam na ficção, em especial em $A$ datilógrafa loura, uma tensão que se torna o suspense do enredo, até a resolução final. A primeira opção em geral é a mais seguida porque, a despeito da exploração que sofre, o operariado é apresentado não como uma classe em vias de tomar consciência da sua particularidade histórica, mas portadora dos ideais daqueles que lhes exploram. Com maior conflito interior e fruto das condições precárias de existência, tal é a opção exemplarmente seguida por Altamira. Os finais das histórias, mesmo com a nota de insatisfação, parecem referendar a permanência do status quo das forças dominantes: no final de A datilógrafa loura, Altamira ia num Renault "afogada em diamantes e peles, de uma beleza triste, quase santa" (p. 167), numa melancolia resoluta e sonambúlica, de quem entregou o corpo e os ideais.

São esses aspectos não programáticos que vinculam o mundo construído nos romances de João de Minas aos escritores e jornalistas 
das primeiras décadas do século XX que se valiam do humor, sarcasmo, caricatura de tipos sociais e ironia (SALIBA, 2002). Todos incorporavam elementos de crítica em suas narrativas, mas não apresentavam um projeto de sociedade. No caso de João de Minas, sua representação dos "proletários" (em sua obra o termo também possui a amplitude de sentido empregada nos anos 30) não leva a nenhuma utopia, seja nacionalista como a do regime Vargas ou comunista como a do PCB ou dos anarquistas. Pelo contrário, se os operários sofrem em sua obra espoliações as mais diversas, por outro lado sonham e/ou se inserem no mundo dos exploradores. Tal perspectiva ambígua e irresoluta deve ter contribuído para o "esquecimento" de sua obra num momento de polarizações políticas e intelectuais.

Nesse sentido, a São Paulo de João de Minas se torna a "Canaã dos flagelados" porque, ao contrário das expectativas, a errância pelo fim do sofrimento operário não termina. Começa.

\section{Referências Bibliográficas}

ALMEIDA, Leandro Antonio de. Sangue de ilusões de João de Minas: um livro esquecido de um autor obscuro. Revista da ASBRAP, n. 12, 2006, p. 47-54.

ADORNO, Theodor. Minima moralia: reflexões a partir da vida danificada. São Paulo: Ática, 1992.

AZEVEDO, Raquel de. A resistência anarquista: uma questão de identidade (19271937). São Paulo: Arquivo do Estado/Imprensa Oficial, 2002.

BUENO, Luís. Uma história do romance de 30. São Paulo: Edusp, 2008.

BULHÕES, Marcelo. Jornalismo e literatura em convergência. São Paulo: Ática, 2007.

COSTA, Cristiane. Pena de aluguel: escritores jornalistas no Brasil - 1904 a 2004. São Paulo: Companhia das Letras, 2005.

DECCA, Maria Auxiliadora Guzzo. A vida fora das fábricas: cotidiano operário em São Paulo (1920-1934). Rio de Janeiro: Paz e Terra, 1987.

EL FAR, Alessandra. Páginas de sensação: literatura popular e pornográfica no Rio de Janeiro (1870-1924). São Paulo: Companhia das Letras, 2004. 
FAUSTO, Boris. Trabalho urbano e conflito social no Brasil. 4. ed. São Paulo: Difel, 1986.

FREIRE FILHO, Aderbal. Quem é esse cara? In: MINAS, João de. A mulher carioca aos 22 anos. Rio de Janeiro: Dantes, 1999, p. 211-266.

HARDMAN, Francisco Foot. Nem pátria, nem patrão: vida operária e cultura anarquista no Brasil. São Paulo: Brasiliense, 1983.

MEYER, Marlise. Folhetim: uma história. São Paulo: Companhia das Letras, 1996.

MINAS, João de. A datilógrafa loura (romance da mulher proletária em São Paulo). Rio de Janeiro: Calvino Filho, 1934.

. Uma mulher... mulher! São Paulo: Editorial Paulista, 1934.

. Nos misteriosos subterrâneos de São Paulo. São Paulo: Imprensa Americana Editora, 1936.

. Pelas terras perdidas. São Paulo: Editorial Paulista, 1934.

. Falando ao operariado de Minas e do Brasil. O Paiz, Rio de Janeiro, 27/07/1929, p. 1.

PINTO, Maria Inês Machado Borges. Cotidiano e sobrevivência: a vida do trabalhador pobre na cidade de São Paulo, 1890-1914. São Paulo: EDUSP, 1994.

PRONKO, Marcela Alejandra. Crônica de um fracasso: uma história dos projetos de criação de Universidades do Trabalho no Brasil. Educ. Soc. [online]. 1999, v. 20, n. 66, p. 84-103. Disponível em: <http:/www.scielo.br/scielo.php?script=sci_artte xt\&pid=S010173301999000100005\&lng=pt\&nrm=iso $>$. Acesso em: 02/02/2007.

RAGO, Margareth. Do cabaré ao lar: a utopia da cidade disciplinar. Brasil: 18901930. 2. ed. São Paulo: Paz e Terra, 1987.

. Os prazeres da noite: prostituição e códigos da sexualidade feminina em São Paulo, 1890-1930. Rio de Janeiro: Paz e Terra, 1991.

. Trabalho feminino e sexualidade. In: DEL PRIORE, Mary (Org.). História das mulheres no Brasil. São Paulo: Contexto, 1997, p. 578-606.

RESENDE, Beatriz A volta de Mademoiselle Cinema. In: COSTALLAT, Benjamin. Mademoiselle Cinema. Rio de Janeiro: Casa da Palavra, 1999, p. 9-27.

RICOEUR, Paul. Tempo e narrativa. Campinas: Papirus, 1994-1997 (1983-1985), $3 \mathrm{v}$.

. Interpretação e ideologias. 3. ed. Rio de Janeiro: Francisco Alves, 1988. 
SALIBA, Elias Thomé. Histórias, memórias, tramas e dramas da identidade paulistana. In: PORTA, Paula. História da cidade de São Paulo, v. 3: A cidade na primeira metade do século XX. São Paulo: Paz e Terra, 2004, p. 555-587.

. Raizes do riso. São Paulo: Companhia das Letras, 2002.

SEIXAS SOBRINHO, J. Sessenta anos depois tarefeiro da imprensa chega ao estrelato. Minas Gerais, Belo Horizonte, n. 2, sexta 04/01/1991, p. 8-9.

Recebido em 06/06/2007. Aprovado em 31/10/2010. 